\title{
Statyba
}

\section{FORMING AND AUTOMATED ENERGY ANALYSIS OF INTEGRATED MODELS OF THE PUBLIC BUILDINGS AND THEIR ENCLOSING STRUCTURES}

\author{
G. Kazakevičiūtè , G. Cinelis \& Z. Kamaitis
}

To cite this article: G. Kazakevičiūte , G. Cinelis \& Z. Kamaitis (2000) FORMING AND AUTOMATED ENERGY ANALYSIS OF INTEGRATED MODELS OF THE PUBLIC BUILDINGS AND THEIR ENCLOSING STRUCTURES, Statyba, 6:3, 147-157, DOI: $10.1080 / 13921525.2000 .10531580$

To link to this article: https://doi.org/10.1080/13921525.2000.10531580

$$
\text { 册 Published online: } 26 \text { Jul } 2012 .
$$

Submit your article to this journal

\footnotetext{
щ Article views: 71
} 


\title{
VIEŠOSIOS PASKIRTIES PASTATŲ IR JŲ ATITVARŲ KONSTRUKCIJŲ INTEGRUO- TŲJŲ MODELIŲ FORMAVIMAS IR AUTOMATIZUOTA ENERGETINE் ANALIZE்
}

\author{
G. Kazakevičiūtè, G. Cinelis, Z. Kamaitis \\ Vilniaus Gedimino technikos universitetas
}

\section{Ivadas}

Pastaraisiais metais vis labiau rūpinamasi energijos taupymu pastatuose ir šilumosauga. Leidžiami nacionaliniai norminiai dokumentai $[1,2,3,4]$, šiuolaikinių projektavimo sprendimy katalogai $[5,6]$, šia tema publikuojami straipsniai [7], kuriamos kompiuteriu programos. Visa tai labai reikalinga, kai reikia projektuoti ir renovuoti objektus, atsižvelgiant i energetinius veiksnius.

Taciau šiuo metu mūsų šalyje kol kas nèra metodikos, kuri leistu operatyviai analizuoti pastatų erdvinę ir konstrukcinę sandara, kompleksiškai vertinti ju projektus energetiniu atžvilgiu. Ši uždavini galima išspręsti panaudojant informacines technologijas. Naujai projektuojamo arba renovuojamo statybos objekto energetiniam ivertinimui reikia disponuoti geometrinių, fiziniu ir ekonominiu duomenų, sujungtų i geometrini skaitmenini objekto informacini CAD modeli, visuma. Šiuo atveju integruotieji modeliai - tai ivairiarūšiai duomenys, tarpusavyje susieti remiantis tos pačios sistemos vidine duomenų baze. Integruotieji modeliai gali būti traktuojami kaip universali duomenų bazè, kuri gali būti panaudota atnaujinant projektavimo dokumentus objekto rekonstrukcijos atveju, nustatant energijos poreikius ir rengiant energetikos auditų medžiagą.

Mūsų tyrimų tikslas yra sukurti metodines ir programines naujai projektuojamy ir renovuojamu pastatu erdvinès ir konstrukcinès sandaros energetinès analizès priemones, kurios būtų suderintos su Lietuvos klimatologinių, šiluminès technikos ir kitų normų reikalavimais bei ekonominio vertinimo metodais ir duomenimis.

Straipsnyje aptarsime esamas pastatu energetinès analizès metodines ir programines priemones, mūsu sukurtu metodikų, sujungtų i vieną specalizuotą CAD sistema, skirtu grafiniams skaitmeniniams modeliams formuoti, bendrus bruožus ir skirtumus, pastato modelio variantų formavimo ypatumus, energetiniu ir ekonominiu atžvilgiu vertinant erdvinius sprendimus, konstrukciją.

\section{Pastatų energetinès analizès metodinių ir progra- minių priemonių apžvalga}

Šiuo metu yra sukurta nemaža programų, skirtų automatizuoti ivairius statybinès šiluminès technikos skaiciavimus ir spręsti pastatų modeliavimo grafinius geometrinius uždavinius.

Pastaruoju metu Lietuvoje naudojamos šios programos, skirtos ivairiems statybinès šiluminès fizikos uždaviniams spręsti [8]:

$\checkmark$ META, ASI - skaičiuojami konstrukciniụ mazgu temperatūriniai laukai;

$\checkmark$ PEP (,Pastato energetinis pasas“), ASI - nustatomas šilumos kiekio pastatuose suvartojimas;

$\checkmark$ SMAIN2, ASI - skaičiuojamas nestacionarusis temperatūrinis režimas pastatuose;

$\checkmark$ DRÉGMÉ, ASI - skaičiuojamas nestacionarusis drègmès režimas pastatuose;

$\checkmark$ algoritmai ir programos atitvaru šilumos perdavimo koeficientams skaičiuoti, atitvaru izoliaciniu medžiagu storiui parinkti ir pan. (parašyti pagal SNIP, RSN).

Apžvelgus Lietuvoje sukurtas metodines ir programines priemones, galima teigti, kad:

- jomis sprendžiami tik atskiri daliniai pastato energetinès analizès uždaviniai,

- jos remiasi tik skaitiniais metodais, o grafiniai vaizdai turi tik iliustracinę paskirti.

Tarp populiariausių užsienyje naudojamu programų yra nedaug tokių, kuriose būtų integruota grafinè skaitinè informacija, naudojama pastato erdvinès ir konstrukcinès sandaros analizei energetiniu atžvilgiu. Galima būtu paminèti amerikiečiu programą AutoArchitect+Energy (Autodesk Inc.) [9] ir vokiečių ALLKLIMA 2000 (Nemet- 
schek $G b m H$ ) [10], nors pastarojoje daugiau dèmesio skiriama inžineriniu sistemų projektavimui pastate nei pastato erdvinès ir konstrukcinès sandaros modeliavimui. Šiose programose naudojami klimatologiniai ir ekonominiai duomenys yra paimti iš vietinių normatyvinių dokumentų ir neatitinka Lietuvos sąlygų.

Specifinę grupę sudarytų programos, kuriose grafiné informacija integruota su skaitine, bet jos naudojamos projektuojant atskiras pastato dalis (pvz., langus) ar iranga:

$\checkmark$ FRAME. Enermodal Engineering - apskaičiuojamos langu šiluminés savybès ir parenkama langy konstrukcija ir orientacija pasaulio šalių atžvilgiu:

$\checkmark$ Minètoji ALLKLIMA 2000, Nemetschek - projektuojamos ir apskaičiuojamos pastatų inžinerinès sistemos (šildymo, védinimo ir vandentiekio kanalizacijos).

Skaitine informacija operuojančių programų pavyzdžiai yra šie:

$\checkmark$ Wärme-Dampf (Vokietija) - leidžia varijuoti atitvaru konstrukcinius sprendimus, parenkant medžiagas, turinčias tam tikras charakteristikas, ir atlikti šilumos poreikio skaiciavimus renovuojamiems bei naujai statomiems pastatams.

$\checkmark$ Excel+Ebriga, Energie- und Unweltzentrum in Springe-Eldagsen [11] - pasirinkus tam tikrus fizikinius parametrus, apskaičiuojamas pastato energetinis balansas.

Geometrinè informacija pastatų modeliams aprašyti yra naudojama visose siuolaikinèse projektavimo sistemose. Populiariausios iš jų yra šios:

$\checkmark$ AutoCAD Architectural Desktop, Autodesk (JAV) [12] - skirta kurti architektūriniams bei konstrukciniams pastatų ir statinių modeliams, skaičiuoti plotams ir tūriams.

$\checkmark$ ArchiCAD, Graphisoft (Vengrija) [13] - skirta architektūriniam-statybiniam ir dizaino projektavimui. plotu, perimetru ir projekto sąmatoms apskaiciuoti.

$\checkmark$ ALLPLAN FT, Nemetschek (Vokietija) - skirta architektūriniam bei konstrukciniam projektavimui, plotų. tūrių skaičiavimui ir kt.

$\checkmark$ MicroStation TriForma, Bentley Systems (JAV) skirta architektūriniams ir konstrukciniams-statybiniams bréžiniams generuoti, projekto sąmatai skaičiuoti. $\checkmark$ ArCon, Softurare (Vokietija) (išversta i lietuvių kalba, firma AGA) - skirta pastato architektūriniams brèžiniams generuoti ir apskaičiuoti plotams, tūriams ir atskirų elementụ medžiagų kiekiams.

Kiekvieną iš šiu sistemu galima adaptuoti specializuotiems uždaviniams (tarp ju ir energetinès analizès) spręsti. Tačiau tiesiogiai jos nèra tam skirtos.

\section{Pastatų erdvinès ir konstrukcinès sandaros mode-} liavimo ir energetinio vertinimo automatizuotos sistemos charakteristika

Specializuotą pastatų modeliavimo ir energetinès analizés sistemą realizavome atvirosios architektūrinio kompiuterinio projektavimo sistemos AutoCAD aplinkoje. Ji remiasi $A u t o C A D$ grafinio redaktoriaus ir programy kürimo priemonèmis. Svarbiausi specializuotos sistemos elementai yra integruotieji grafiniai skaitmeniniai modeliai, jungiantys informacija apie pastatą ir jo dalis, ir matematinès modeliu apdorojimo ir sistemos funkcionaluma užtikrinančios priemonès.

Automatizuotą pastaty energetinès analizès sistemą šiame tyrimu etape sudaro tokios pagrindines dalys (1 pav.):

- pastatų komplekso ar pastato ir jo dalių apibendrinto geometrinio modeliavimo posistemis;

- pastato daliu konstrukcijos geometrinio modeliavimo posistemis;

- pastato modelio metrikos analizès posistemis;

- pastato modelio energetinès analizès posistemis;

- projektų variantų vertinimo ir peržiūros posistemis. Trumpai aptarsime visas sistemos dalis ir jos funkcionavimo ypatumus.

\begin{tabular}{|c|c|c|c|}
\hline \multicolumn{4}{|c|}{ Pastatu energetinés analizès CAD sistema } \\
\hline $\begin{array}{l}\text { Geometrinio } \\
\text { modeliavimo } \\
\text { posistemis }\end{array}$ & \multicolumn{2}{|c|}{ Analizès posistemiai } & $\begin{array}{c}\text { Peržiūros ir } \\
\text { vertinimo } \\
\text { posistemis }\end{array}$ \\
\hline $\begin{array}{l}\text { pastatu } \\
\text { komplekso ir } \\
\text { pastato dalių }\end{array}$ & \multirow{2}{*}{$\begin{array}{l}\text { pastato } \\
\text { mode- } \\
\text { lio } \\
\text { metri- } \\
\text { kos }\end{array}$} & \multirow{2}{*}{$\begin{array}{l}\text { pastato } \\
\text { mode- } \\
\text { lio } \\
\text { ener- } \\
\text { getikos }\end{array}$} & \multirow[t]{2}{*}{$\begin{array}{l}\text { projektų } \\
\text { variantų }\end{array}$} \\
\hline $\begin{array}{l}\text { pastato dalių } \\
\text { konstrukcijos }\end{array}$ & & & \\
\hline
\end{tabular}

1 pav. Pastaty erdvinès ir konstrukcinès sandaros modeliavimo ir energetinès analizès sistemos struktūra

Fig 1. The structure of building modelling and energy analysis system 
Pirmoji bei antroji metodikos dalys yra susijusios su pastatų ir ju dalių geometrinių modelių kūrimu. Geometriniai modeliai gali būti formuojami keliais būdais.

Pirmasis būdas realizuojamas, naudojantis „TiVa“ (,Tipai ir variantai“) programu, itrauktu i bendrą sistema, kompleksu. Naudojantis programinemis priemonemis kuriami erdviniai (3D) profiliai, kurie gali būti ịterpiami iš CAD duomenu bazès i grafini langą, transformuojami bei detalizuojami. Taip formuojamas pastato apibendrintas erdvinis modelis, aprašomas išorinemis atitvaromis. Pastato modelis sudaromas iš $3 \mathrm{D}$ stačiakampès geometrijos profilių. Išorinès atitvaros - 3D profilių plokštumos su angomis arba be jụ. Toliau detalizuojant pastato erdvini modelị. jo vidinis türis gali būti skaidomas i atskiras patalpas, naudojant sukurtus 3D profilius.

Pagrindiniai principai, igyvendinti komplekse „Ti$\mathrm{Va}{ }^{\prime}$ :

- operatyvus ir laisvas objektų formų (profilių) kūrimas;

- projektavimo žodyno iš 3D profiliu sudarymas praktiškai ji realizuojant kaip grafinę duomenų bazę;

- ryšių tarp skirtingų profilių detalizacijos lygiụ nustatymas ir laisvas jụ keitimas modelyje:

- metodu variantiniam projektavimui taikymas.

Kitas būdas, itrauktas i sistemą, taip pat skirtas kurti projektuojamo ar rekonstruojamo pastato modeli ir jo dalis. Šiuo atveju taikomos skenavimo ir rastrinių vaizdu apdorojimo technologijos. Rastriniai vaizdai - tai pastato dvimačiai architektūriniai bréžiniai (aukštų planai, fasadai ir kt.), kurie imami iš esamu projektavimo dokumentụ. Sukūrus pastato dalių rastrinius failus, jie perkeliami i AutoCAD aplinką. Toliau rastriniai vaizdai apdorojami programinio komplekso priemonemis. Pirmiausia jie vektorizuojami, vèliau formuojami dvimačių aukštų planu scheminiai vaizdai, pastato duomenu failai, vèliau kuriamas pastato ir jo dalių erdvinis modelis. Toliau detaliau aptariamas šis programų kompleksas.

Skenuotos ortogonaliosios pastatu projekcijos (planai, pjūviai, fasadai ar kt.) apdorojamos dinaminio vektorizavimo programinèmis priemonemis: laisvos formos kreivių dinaminio generavimo programa ir ,dinaminè polilinija“, leidžiančiomis operatyviai ir pakankamai tiksliai bet kurioje bréžinio vietoje generuoti atitinkamus CAD esinius. Rastriniai vaizdai taip pat gali būti apdorojami Autodesk specializuota programa CAD Overlay.
Nubraižius pastato aukštu planu scheminius brěžinius, programiškai išanalizavus vidinę kiekvieno scheminio CAD bréžinio duomenų bazę ir vartotojui dialoginiu būdu ją papildžius reikiamais duomenimis, informacija apie modeilo grafinius objektus struktūrizuojama ir išvedama ị tekstinị duomenų failą ( 2 pav.).

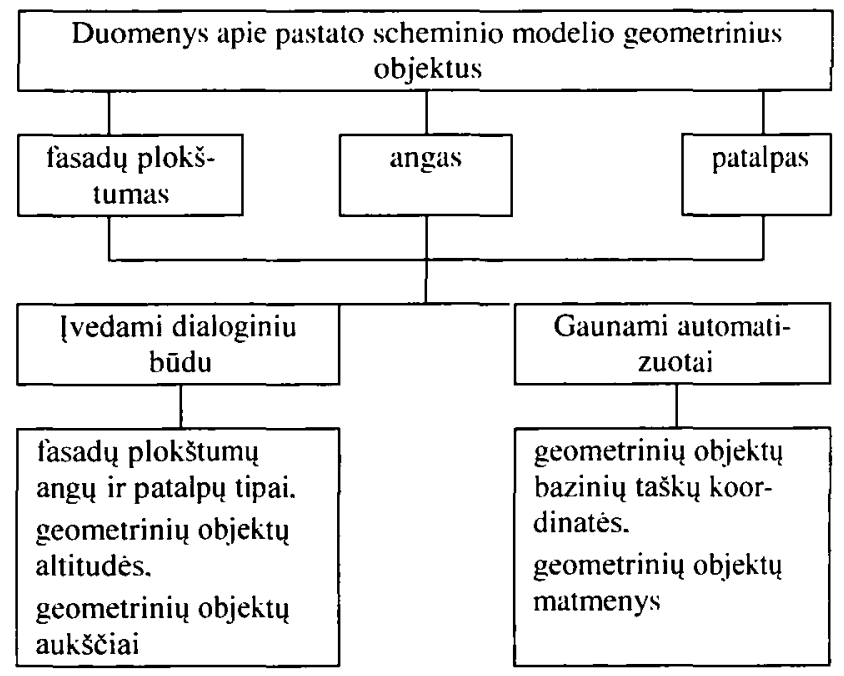

2 pav. Pastato modelio duomenụ failo struktūra

Fig 2. The structure of the building model data file

Remiantis skaitinių duomenų failu automatiškai generuojamas ir vizualizuojamas scheminis erdvinis pastato modelis. Erdvinio pastato modelio paviršiai: išorinès sienos, angos, perdangos - yra aprašomi keturkampemis ir trikampèmis plokštumomis (3Dface grafiniai esiniai), vidinès sienos - polilinija, turinčia aukštị ( $2.5 \mathrm{D}$ grafiniai esiniai), kuri gali būti konvertuojama i 3Dface plokštumas. Erdvinio pastato modelio paviršiai - 3Dface plokštumos gali būti konvertuojamos ir i Region tipo grafinius objektus.

Bendras pastato modelio tūris yra suskaidytas ị dalinius tūrius, imant tokią pastato modelio geometrinio aprašymo schemą: pastatas $\rightarrow$ pastato aukštai $\rightarrow$ aukštu patalpos.

Pastato vidini tūri nuo išorès skiria atitvaros (sienos su langais ir durimis, stogas, nešildomo rūsio ir nešildomos pastogès perdanga), kurios priklauso atitinkamiems aukštams. Fasadu plokštumos geometriniame modelyje yra klasifikuojamos, priskiriant jas tam tikram tipui pagal sienų medžiagas ir jų konstrukcijas. Angų tipai yra siejami su skirtinga jas užpildančių langų ir durų medžiaga ir konstrukcija. Pastato patalpų tipai priklauso nuo jų vidaus temperatūrinio režimo. 
Pastato modelio dalių rūšiavimas pagal paskirti (išorinès ir vidinès sienos, rūsio sienos, cokolis, išorinių sienų langai ir durys, tarpaukštinès perdangos, stogai), tipus (pvz., patalpos) ir aukštus vẻliau leidžia apskaičiuoti reikiamus geometrinius dydžius ir sudaryti pastato modelio atitinkamus erdvinius vaizdus ar ortogonaliąsias projekcijas (planus, fasadus). Modelio vizualizacija palengvina vartotojo interfeiso priemonès.

Aptarti metodai, kurie taikomi kuriant erdvini pastato modelị ir jo dalis, turi šiuos bendrus bruožus:

1) modeliu formavimas paremtas jụ ortogonaliaja geometrija;

2) naudojami tie patys grafiniai esiniai (2.5D polilinija, 3Dface plokštumos);

3) galima modelio detalizacija ivairiuose modelio kūrimo etapuose, t.y. objekto išorinio kontūro, objekto paviršiaus, bendro objekto tūrio detalizacija.

Generuojant pastato modeli minètaisiais būdais, formuojamos šios grafinès duomenų bazès: ivairios formos ir sudètingumo profilių, pastato dalių - duru ir langu ( 3 pav.) bei pastato fasadų konstrukcinių medžiagu. Grafines duomenu bazes galima pildyti tiek automatizuotai. tiek ir dialoginiu būdu.

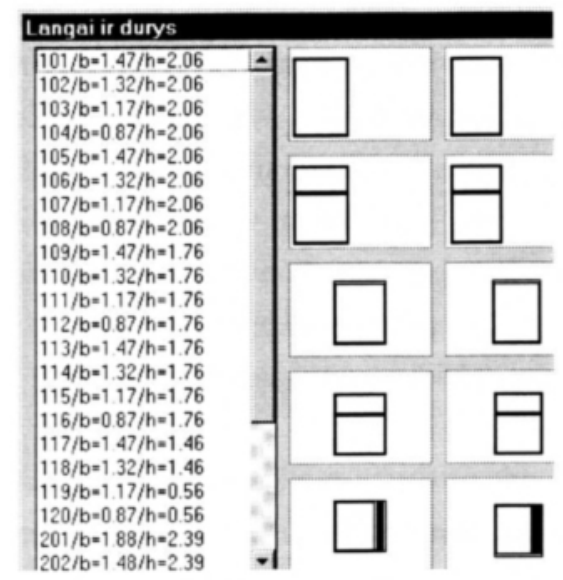

3 pav. Durụ ir langụ grafinè duomenụ bazè

Fig 3. The graphical database of doors and windows

Reikia pažymèti, kad pastatas gali būti sumodeliuotas ir kitais būdais bei kitomis pramoninio kompiuterinio projektavimo sistemomis (pvz., AutoArchitect, Softdesk Inc.). Svarbiausia - tai turi būti CAD modelis, pateiktas elektronine forma.

Toliau aptarsime atitvarinių pastato dalių konstrukcijos modeliavimo būdus. Pastatų dalių konstrukcija aprašoma ịvairiai sluoksniais išdèstomomis konstrukci- nèmis ir šilumą izoliuojančiomis medžiagomis bei ryšiais tarp sluoksnių.

Pastato modelio atitvarų konstrukcijos apibréžimo klausimas automatizuotoje sistemoje sprendžiamas dvejopai:

- automatizuotu būdu grafiškai formuojant atitvaros su pageidaujamomis šiluminemis savybèmis skerspjūvio schemą;

- naudojantis iš anksto parengtais konstrukcinių sprendimų grafiniais skaitiniais modeliais, saugomais sistemos duomenų bazeje.

Pirmuoju būdu formuojant pastato erdvinio modelio atitvarinių dalių konstrukciją naudojami dvimačiai (2D) modeliai. kurie yra generuojami brěžinio plokštumoje, vaizduojant atitvaros skerspjūvio sandarą. Taip grafiškai iforminti 2D modeliai ivvedami i grafinę duomenų bazę, iš kurios vèliau jie gali būti išrenkami ir modifikuojami. Formuojant atitvaros skerspjūvio sandarą apskaiciuojami ir objekto energetinei analizei reikalingi parametrai (šiluminé varža $R$ ir šilumos perdavimo koeficientas $U$ ). Grafiniai skaitmeniniai 2D modeliai turi CAD bloku, integruotų su atributiniais duomenimis (Attributes), arba esiniu su papildančiais duomenimis (Extended data) formą.

4 pav. pavaizduota objekto modelio atitvaru konstrukcijų ir gaminių iš anksto parengtas šiuolaikinius šiluminius techninius reikalavimus atitinkančių (pvz., firma Isover) konstrukcinių sprendimų ir gaminių grafinès skaitinès duomenų bazès skaidrių meniu. I šią duomenų bazę gali būti ịtraukti $A u t o C A D$ ar kita kompiuterinio projektavimo sistema generuoti vektorinès grafikos blokai failai,

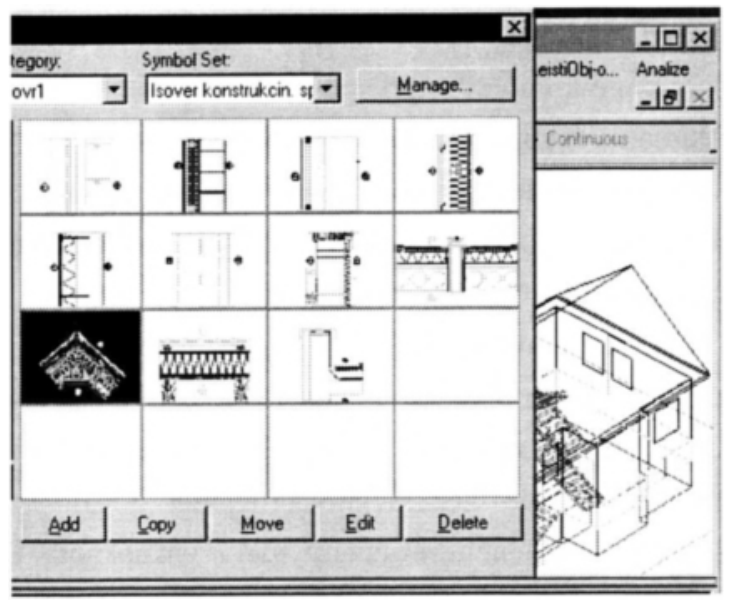

4 pav. Pastato modelio atitvarinių daliụ konstrukcinių sprendimų grafinè skaitiné duomenų bazé

Fig 4. The graphical digital database for structural solutions of the building model cladding parts 
aprašyti struktūrizuotais papildomais tekstiniais ir skaitiniais duomenimis.

Ivairiu pastato dalių konstrukcinių sprendimų rinkiniui kaip grafinei skaitinei duomenu bazei formuoti naudota efektyvi šios rūšies programinè priemonè - firmos Softdesk Inc. programa AEC Tools, o tiksliau jos dalis simbolit valdymo programa (Symbol Manager). Siekiant užtikrinti patogią programinių modulių tarpusavio sąveika ir maksimaliai automatizuoti darbo procesa, sukurta taikomoji programinė iranga yra programiškai suintegruota su simboliu valdymo programa.

Ir pirmuoju, ir antruoju atveju negrafiniai duomenu bazès elementų duomenys (konstrukcijų pavadinimai, šiluminès techninès charakteristikos) yra asocijuojami su geometrinio modelio elementais.

Pastato modelio metrikos analizès dalis skirta automatizuotai nustatyti modelio atitvarų plotus, patalpu tūrius bei perimetrus.

Vienu atveju informacija apie pastato modelio dalis išvedama ekrane:

Command: Pagal sluoksnio vardq - s / rinkti plokštumas - $r$ / dvieju plokšsumı atitvaros sluoksniuose - d/ visas modelis $-v<r>$ ?

Surinkite modelio plokštumas..

Select objects: $n$

First corner: Other corner: 35 found

Ar spausdinti ekrane apskaičiuotu plotu reikšmes? $\langle t>$.

Apskaičiuotas plotas $=53,37 \mathrm{~m}^{2}$.

Informacija yra saugoma operatyviojoje atmintyje ir vartotojo pageidavimu gali būti sudedamos atskiru skaičiavimo rezultatų eilutès.

Kitu atveju ši informacija gali būti išvedama i tekstini failą, kuriame atitvarụ tipai rūšiuojami pagal sluoksnius. Tekstinio failo, sudaryto iš dviejų dalių, struktūra pateikta 5 pav. (a, b). Šiame faile pateikiamos ir pastato aukštų perimetru skaitinès reikšmès.

Atliekant pastato energetinę analizę erdvinio modelio atitvarinių dalių tekstiniai ir skaitiniai duomenys (konstrukciju pavadinimai. šiluminès techninès charakteristikos, geometriniai dydžiai) yra išfiltruojami ir naudojami energetinio vertinimo rodikliams skaičiuoti.

Specializuotoje sistemoje pastato energetiniam vertinimui gali būti numatytos ir vartotojo nuožiūra pasirenkamos ịvairios skaičiavimo metodikos. kuriose atsižvelgiama $\mathrm{i}$ šalies normų reikalavimus („.Pastato energetinis pasas“, ASI; „Šilumos suvartojimas gyvenamiesiems namams šildyti norminiais pagal klimatą metais", doc. M. Gedgaudas [14]; ,.Pagalbinè medžiaga konsultantui“", Būsto kreditavimo fondas [15] ir kt.). Aptariamoji atviros architektūros sistema leidžia lengvai aprašyti minėtųju metodiku matematines išraiškas.

a)

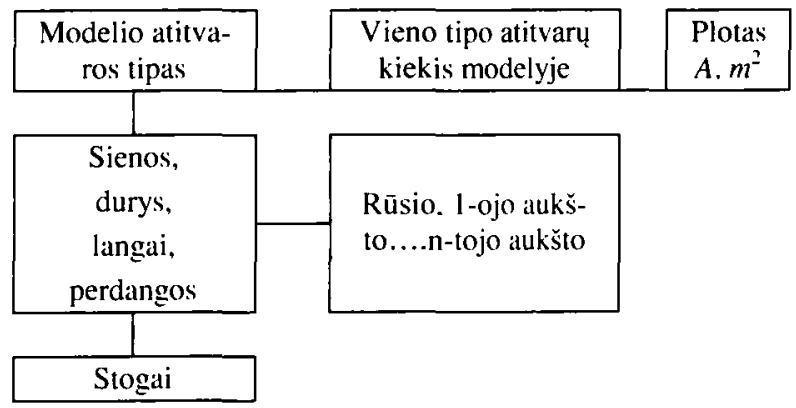

b)

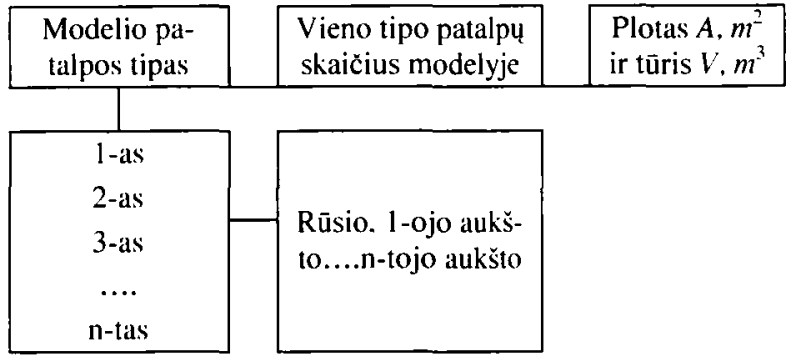

5 pav. Tekstinio failo struktūra: a - 1-a tekstinio failo dalis. kurioje pateikti atitvary plotai: $b-2-a$ tekstinio failo dalis, kurioje pateikti patalpų plotai ir tūriai

Fig 5. The structure of text file: a - the first part of the file, where areas of cladding components are presented: $b$ the second part of the file, where room areas and volumes are presented

Šiuo metu automatizuotoje sistemoje naujai projektuojamų ir renovuojamų pastatų energetiniam vertinimui yra taikomi du būdai.

Pirmuoju atveju energetinio vertinimo rodiklis yra pastato ar jo dalių atitvaru savitieji šilumos energijos nuostoliai, kurie yra normuojami naujajame statybos techniniame reglamente [1]:

$$
H_{T}=\Sigma A_{i} \times U_{i}+\Sigma \Psi_{i} \times l_{i}, \quad W / K,
$$

$A_{i}$ - atitvaros plotas, $\mathrm{m}^{2} ; U_{i}-$ atitvaros šilumos perdavimo koeficientas su pataisomis, $W /\left(m^{2} \times K\right) ; \Psi_{1}$ - pataisa dèl ilginio šalčio tiltelio, $W /(m \times K): l_{i}$ - šalčio tiltelio ilgis, $n$.

Savitieji pastato šilumos energijos nuostoliai yra rodiklis, patogus vertinti projektu variantus, nes jis ivertina 
objekto geometriją ir konstrukcija, tačiau neatsižvelgia i konkrečią statybos vietą, t. y. i klimatologines sąlygas.

Antruoju atveju pastato energetinei analizei taikoma paprasta, bet pakankamai tiksli metodika [14]. Ji skirta apskaičiuoti, kiek per metus suvartojama šilumos gyvenamiesiems namams šildyti norminiais metais (tokiais, kuriu šildymo sezono trukmè ir vidutine lauko oro temperatūra tuo laikotarpiu atitinka duomenis, nurodytus respublikinèse statybos normose "Statybine klimatologija”. RSN 156 - 94), $Q_{m e t,}$ kurie susidaro dèl šilumos nuostoliu per išorines atitvaras $Q_{s}$ ir dél patalpų vedinimo $Q_{v}$. Metodika taip pat iš dalies ivertina vidinius šilumos pritekèjimus šildymo sezono laikotarpiu $Q_{b}$. Metinis šilumos suvartojimas namui šildyti apskaičiuojamas pagal formulę:

$$
Q_{\text {met. }}=0.9 \times\left(Q_{s}+Q_{v}\right)-Q_{b}, \quad k W h .
$$

Metodika taikoma renovuojamy pastaty energetinei analizei atlikti.

Projektų variantų vertinimo ir peržiūros posistemis leidžia atrinkti racionaliausius projektų erdvinius ir konstrukcinius sprendimus energetiniu ir ekonominiu atžvilgiais.

Pastato projekto variantai gali būti formuojami keičiant pastato erdvinius sprendimus, atitvarų dydžius bei jų konstrukcija ( 6 pav.). Pastato erdvinius sprendimus ir atitvarų dydžius apibūdina jų geometriniai parametrai (ilgis, plotis, aukštis ir pan.), o atitvaru konstrukciją šiluminių rodiklių reikšmès, kurios priklauso nuo medžiagu išdéstymo atitvaros sluoksniuose ir ryšių tarp sluoksnių. Operuojant šiais dydžiais, projektai peržiūrimi ir ivertinama, kaip kinta jụ energetiniai (pvz., savitieji pastato šilumos energijos nuostoliai) ir ekonominiai (populiariausias iš ju - paprastas atsipirkimo laikas, panaudojant nuosavas lèšas) rodikliai (7 pav.).

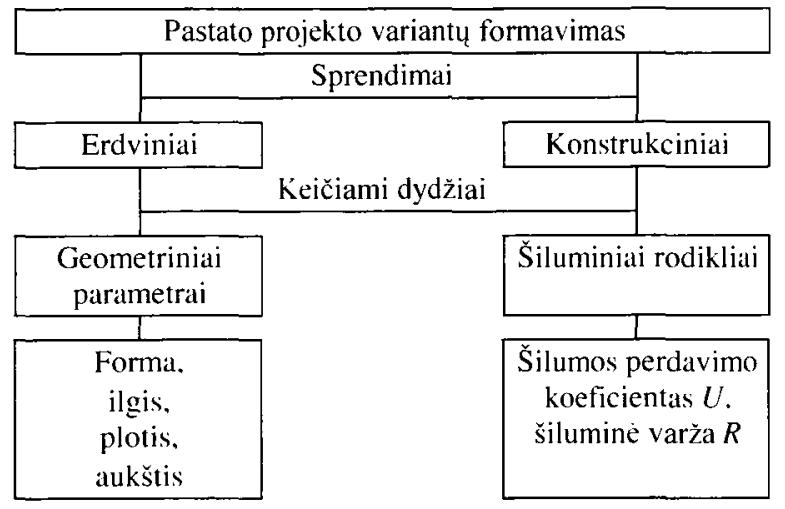

6 pav. Pastato projekto variantiniai sprendimai

Fig 6. The building project variant solutions

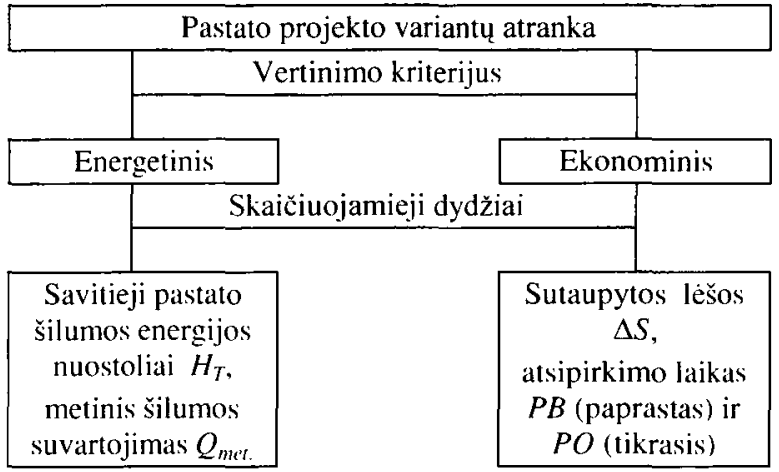

7 pav. Pastato projekto variantų vertinimo kriterijai

Fig 7. The building project variant evaluation criteria

Paprastas atsipirkimo laikas yra paprasčiausias ekonominio vertinimo būdas, apibrèžiamas investicijų ir metinių sutaupytų lèšų santykiu, naudojamas preliminariam projektų variantų vertinimui.

Specializuotoje sistemoje ekonominiai rodikliai yra sutaupytos lèšos ir atsipirkimo laikas (naudojant nuosavas lèšas ir naudojant skolintas lèšas). Apšiltinus atitvaras šie rodikliai skaičiuojami pagal prof. V. Stankevičiaus, inž. G. Dapkaus ir dr. A. Burlingio metodiką [16].

\section{Projektụ variantų formavimo ypatumai}

Projektų variantų formavimo ypatumus nagrinėsime, remdamiesi realiu objektų - naujai suprojektuoto ir renovuojamo - pavyzdžiais.

Pirmasis suprojektuotas objektas yra komercinès paskirties ${ }^{1}$ ( 8 pav.). Šio objekto matmenys plane $-42,7 \mathrm{~m}$ ir 19,35 m. jis dviejų aukštų, stogas šlaitinis, skirtingu aukščiu ir nuolydžių. Konstrukcinè sistema - nepilnas karkasas. Projektas realizuotas darbo dokumentu rengimo stadijoje.

Kompiuterinio modelio ypatumas yra tas, jog jis buvo generuojamas pramonine kompiuterinio projektavimo programa AutoArchitect (Softdesk Inc.). Aprobacijai jis buvo pasirinktas, norint patikrinti modeliavimo ir energetinès analizès sistemos galimybes dirbant su tokio pat pobūdžio ir sudétingumo modeliais. Be to, nagrinèjamo geometrinio modelio visos sienos ir pertvaros yra grafiškai aprašytos ne viena, o dviem plokštumomis, t. y. sienos turi išorini ir vidini paviršių, o visi angose esantys gaminiai yra AutoCAD blokai. Tokių blokų analizè dabar-

1 Projektuotojas - architektūrinè firma $L \& G$ (architektai L. Tumynienè, G. Vieversys, kompiuterinis modelis G. Cinelio) 
tinèje sistemos versijoje nèra ¿̨manoma, todèl jie grafinio redaktoriaus priemonèmis turèjo būti pakeisti iprastinèmis plokštumomis.

Pirmieji aprašomo modelio programinès analizès bandymai parodè, jog kai kurie sienц paviršiu grafiniai elementai, naudojant jų redagavimui ivairias programas, geometriniu atžvilgiu yra nekorektiški. Šie elementai turi būti identifikuojami ir pašalinami iš modelio. Tai gali būti viena iš pagrindinių kliūcių operatyviai modelio analizei, nes vartotojas turi turèti erdvinių modelių konstravimo patirties.

Parduotuvès modelio plokštumoms buvo priskirti atitvarų, kurios atitinka šiuolaikiniu pastatu atitvaroms keliamus šiluminius reikalavimus, duomenys. Sienu skerspjūviai buvo konstruojami darbo eigoje, o ne naudojamasi duomenų baze. Nagrinejant šio pavyzdžio antraji variantą, stogas buvo keičiamas iš šlaitinio tipo i sutapdintą, taip pat keičiamas langu tipas.

Lentelèje pateikiami modelio ir projekto variantu energetinès analizès rezultatai.

Šiame pavyzdyje projektų variantų vertinimo rodiklis - savitieji šilumos energijos nuostoliai. Ilginių šilumos tilteliu $\Sigma \Psi_{i} \times l_{i}(W / K)$ kol kas metodika nevertina. nes šilumos nuostoliai dèl šio veiksnio sudaro nedidelę bendros ju apimties dali.

Analizuojant rezultatus galima pastebèti, kad suminiai savitieji šilumos energijos nuostoliai abiejuose variantuose skiriasi nedaug, nes projekto pakeitimai, didinantys nuostolius ir juos mažinantys, beveik kompensavo vienas kitą. Tačiau kartu iš esmès buvo pakeistas ir pakartotinai jvertintas architektūrinis konstrukcinis
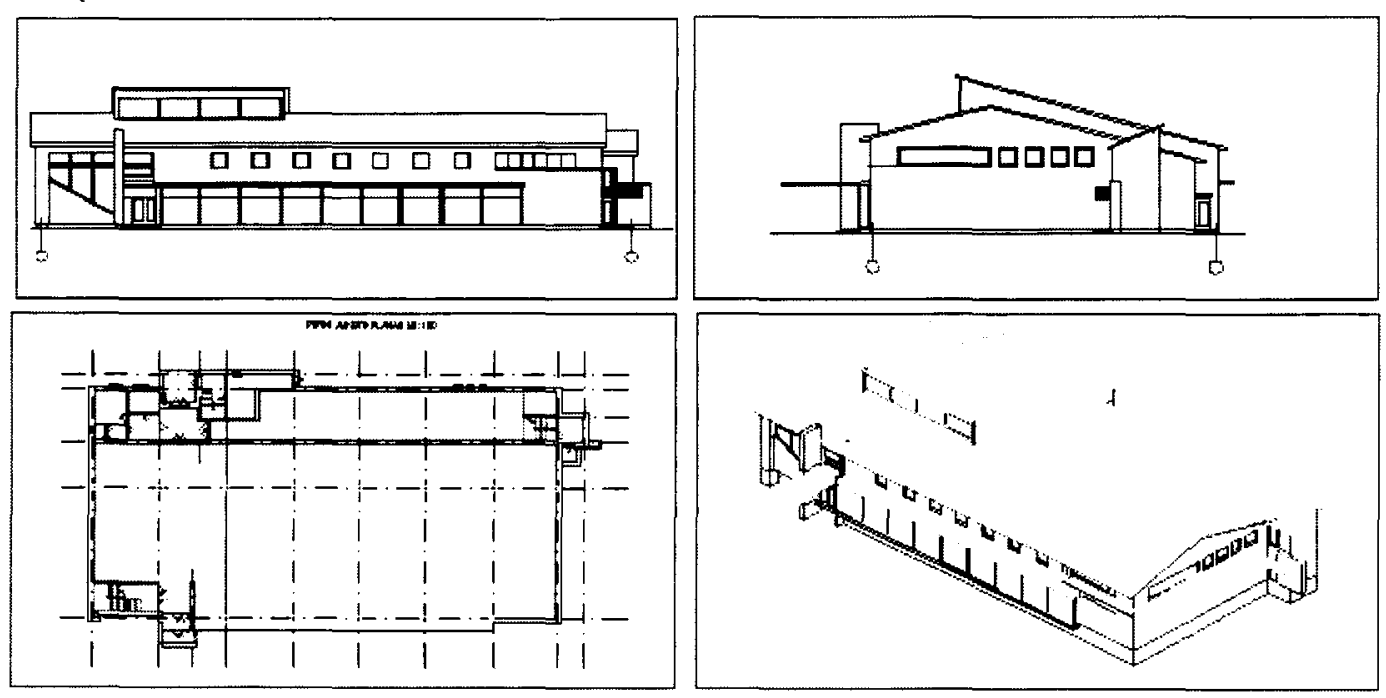

8 pav. Naujai suprojektuoto objekto Marijampoleje kompiuterinis modelis - 2 fasadai, planas

Fig 8. The computer model of a newly designed object in Marijampole. 2 elevations. floor plan 

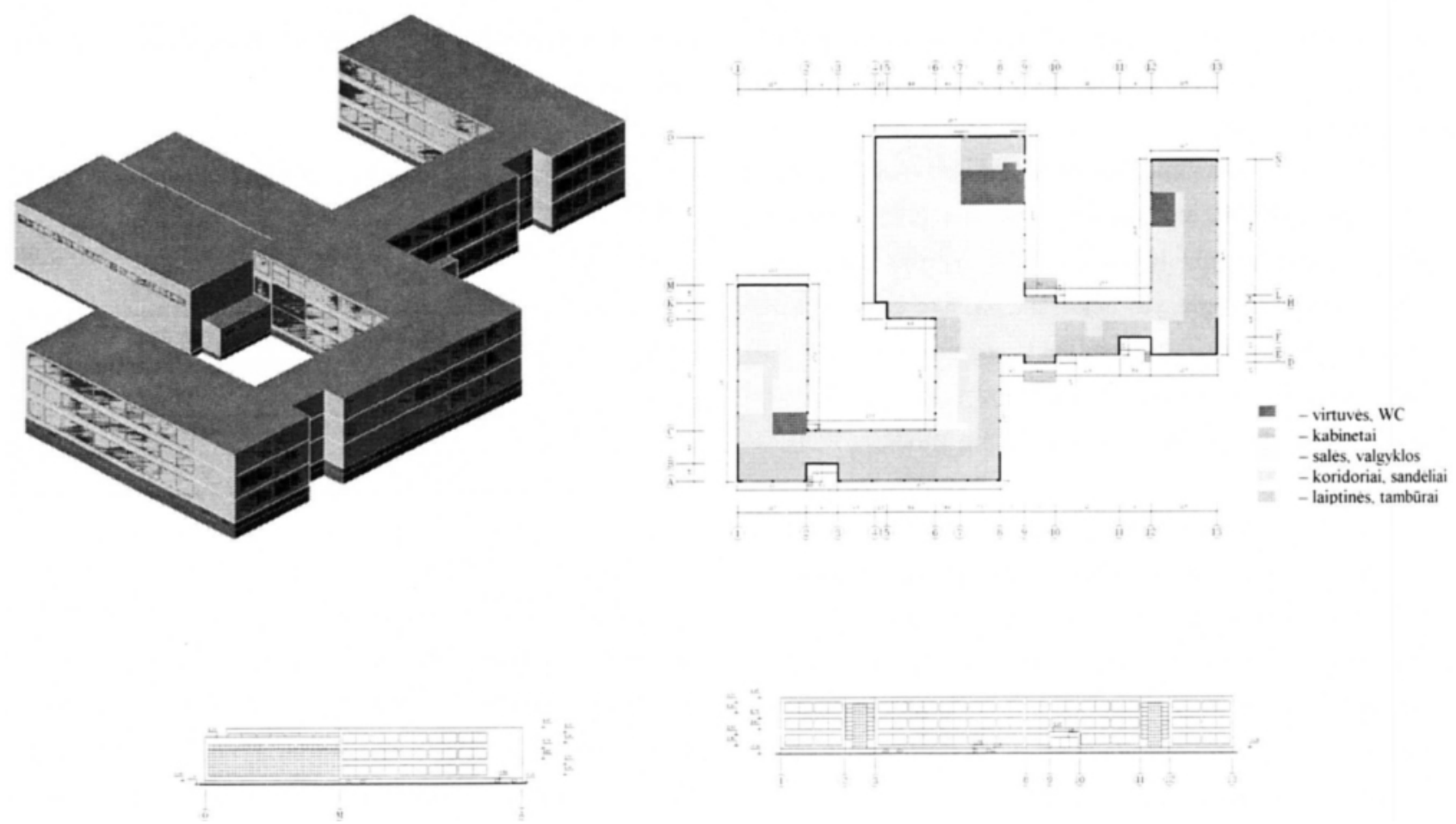

9 pav. Renovuojamos mokyklos Utenoje kompiuterinis modelis, 2 fasadai, 1-o aukšto planas

Fig 9. The computer model of the school under renovation in Utena, 2 elevations, ground floor plan

buvo priskirta šiluminio rodiklio (šilumos perdavimo koeficiento $U$ ) reikšmè, vèliau be kliūčị automatizuotu būdu buvo analizuojamas metrikos, energetiniu bei ekonominiu atžvilgiu.

Nagrinèjami renovuojamo pastato modelio variantai: pirmasis variantas - atspindintis esamą objekto būklę; antrasis - plokščio stogo renovacija, irengiant šilumos izoliacinị sluoksnị ir šiuolaikinę hidroizoliacinę dangą (apšiltinto stogo varža $R=3,5 \mathrm{~m}^{2} \times K / W$ ); trečiasis esamų sienu šiltinimas iš išorès, apdailos sluoksniui panaudojant plonasluoksni tinką (apšiltintų sienų varža $R=3.5 m^{2} \times K / W$ ); ketvirtasis - panaudojamos tos pačios priemonès, kurios pateiktos antrajam ir trečiajam variantams.

10 pav. pavaizduotas šilumos nuostoliu pasiskirstymas per pastato atitvaras pirmojo varianto atveju. Projekto variantų šilumos nuostolių kintamos dalies energetinès analizès rezultatai pateikti grafiškai (11 pav.).

Renovuojamo objekto projekto variantu pagrindinis vertinimo rodiklis - pastato metinis šilumos suvartojimas

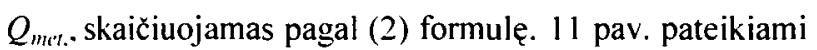
apskaičiuoti suminiai šilumos nuostoliai per skirtingas atitvaras $Q_{s}$ ir lyginamasis šilumos suvartojimas $q_{A}$. Eko-

\section{Q - A priklausomybé}

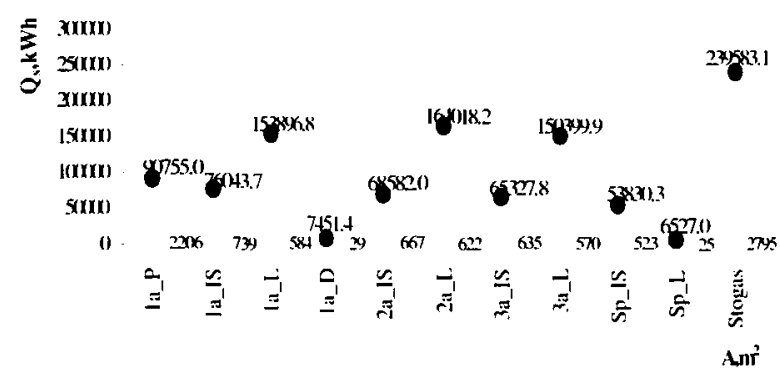

10 pav. Pastato šilumos nuostoliụ $Q_{s}$ priklausomybè nuo jo atitvarų plotų $A$ ir nuo varžų $R$ ( 1 variantas). čia:

Ra_P - rūsio perdanga $\left(R=1 \mathrm{~m}^{2} \times K / W\right)$, la_IS, 2a_IS, 3a_IS, Sp_IS - 1. 2. 3 a. sporto salès išorinès sienos $\left(R=1 m^{2} \times K / W\right), 1 \mathrm{a} \_L, 2 a_{-} L, 3 a_{-} L . S p \_L-1,2,3$ a sporto sales langai $\left(R=0,39 \mathrm{~m}^{2} \times K / W\right)$, 1a_D, 2a_D, 3a_D. Sp_D - 1. 2. 3 a. sporto salès durys $\left(R=0,4 m^{2} \times K / W\right)$. stogas $\left(R=1,2 m^{2} \times K / W\right)$

Fig 10. The dependence of the building heat losses $Q$, upon its areas $A$ of the cladding parts and heat resistivity $R$ (first variant), here:

Ra_P - basement ceiling ( $\left.R=1 \mathrm{~m}^{2} \times K / W\right)$, 1a_IS, 2a_IS, 3a_IS, Sp_IS - 1, 2, 3 a., outer walls of the sport hall $\left(R=1 m^{2} \times K / W\right)$, 1a_L, 2a_L, 3a_L, Sp_L - 1, 2, 3 a sport hall windows $\left(R=0,39 \mathrm{~m}^{2} \times K / W\right)$, 1a._D. 2a_D. 3a_D, Sp_D - 1, 2, 3 a. sport hall doors $\left(R=0,4 m^{2} \times K / W\right)$. the roof $\left(R=1,2 m^{2} \times K / W\right)$ 


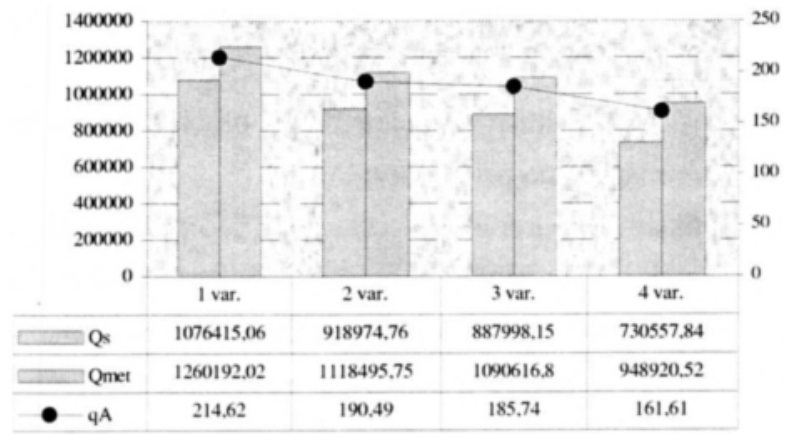

11 pav. Renovuojamo pastato modelio variantu $Q_{s}, Q_{\text {mer }}$ ir $q_{A}$ reikšmių palyginimas

Fig 11. Comparison of indices $Q_{s}, Q_{m e r}$ and $q_{A}$ of variants of the building model under renovation

nominè renovuojamo objekto charakteristika yra sutaupytosios léšos $\Delta S$ ir tikras atsipirkimo laikas, naudojant nuosavas léšas $P O$. Apšiltinus stoga (2 var.), $\Delta S=6,8$ $\mathrm{Lt} / \mathrm{m}^{2} \times$ metai ir $P O=18$ metų. Apšiltinus išorinès sienas (3 var.), $\Delta S=8,8 \mathrm{Lt} / \mathrm{m}^{2} \times$ metai ir $P O=16,6$ metu.

Išanalizavus rezultatus galima teigti, kad suminiai šilumos energijos nuostoliai $Q_{s}$ ir kartu pastato metinis šilumos suvartojimas $Q_{m e t}$ bei lyginamasis šilumos suvartojimas $q_{A}$. visuose variantuose skiriasi, nes projekte atlikti konstrukciniai pakeitimai, t. y. apšiltintas plokščias stogas bei išorinès sienos, dèl to sumažèja $Q_{m e t}(11$ pav.). Šilumos nuostoliai per atitvaras priklauso ne tik nuo ju konstrukcijos varžos, bet ir nuo jų ploto, todèl kuo didesnis atitvarų plotas ir mažesnẻ varža, tuo didesni šilumos nuostoliai (10 pav.). Kai didesnis atitvaros plotas ir kartu didinama jos varža, šilumos nuostoliai per atitvara gali sumažeti daugiau nei esant mažesniam jos plotui.

Šiais pavyzdžiais siekta pademonstruoti kai kurias skirtingų projektų parametrų varijavimo ir jų itakos tyrimo, dirbant automatizuotos sistemos aplinkoje, galimybes.

\section{Specializuotos kompiuterinio projektavimo siste- mos tobulinimo kryptys}

Tobulèjant šiuolaikinėms informacijos technologijoms, kartu dideja ir vartotojo poreikiai, siekiama kuo mažesnèmis laiko sąnaudomis realizuoti geros kokybès projektus, efektyviai atlikti ju analizę. Erdvinio modeliavimo ir energetinès analizès sistemos aprobacija realių objektų pavyzdžiu leido numatyti jos tobulinimo kryptis.

Šiuo metu kvalifikuotai sistemos priemonemis gali naudotis patyręs kompiuterinio projektavimo specialistas, dirbantis sistemos AutoCAD aplinkoje. Daugumą šioje sistemoje numatytu operaciju yra paprasta atlikti, tačiau vartotojui gali kilti sėkmingo ju jungimo i didesnes procedūras ir smulkių, tačiau specifinių redakcinių pataisymų problemos. Kai kurios operacijos yra programiškai realizuotos skirtingose $A u t o C A D$ versijose, kas sudaro nepatogumu praktiškai ją eksploatuojant. Šios problemos galètų būti išspręstos, sukuriant šiuolaikinị sistemos interfeisą ir adaptuojant visas funkcijas vienai $A u t o C A D$ versijai.

Labai svarbus yra pastato erdvinio modelio kūrimo etapas. Šiame etape architektūrinius objektu sprendimus patogiausia yra keisti pradinèje objektu detalizavimo stadijoje. Kai kuriuos projekto parametrus (pvz., atskiru langu, redaguojant visą jų grupę, matmenis) operatyviai keisti yra keblu. tačiau paprasta yra pakeisti objektus vienus kitais (pvz., turinčius $A u t o C A D$ bloku statusą langu gaminius). Todèl tikslinga sukurti parametrizuotus, t. $y$. tam tikromis savitarpio priklausomybemis principu argumentas-funkcija aprašytus objektus ir jų redagavimo algoritmus tipiškiems projektavimo procedūrų atvejams.

Dabartineje sistemos versijoje yra numatyta erdviniu modelių, sudarytų iš plokštumų ir papildytu negrafiniais duomenimis (Extended data), vidinès duomenų bazès filtravimo ir analizès procedūra. Tokios duomenų struktūros gerai tinka tokių pastato dalių, kaip sienos, stogai, perdangos ir panašiais atvejais. Tačiau sistema būtu žymiai universalesnè, jei ji būtu papildyta ìvairių CAD blo$\mathrm{ku}$, asocijuotu su atributiniais duomenimis, apdorojimo algoritmais. Jie natūraliai galètų būti taikomi tam tikrų pastato gaminiu modelių (pvz., langu, duru) atveju.

Kaip jau buvo minèta, pastato modelis gali būti sukurtas nebūtinai straipsnyje aptariamos sistemos priemonèmis. Apdorojant modeli, suformuotą kitomis programinèmis priemonèmis ar pramoninèmis CAD sistemomis, pasitaikančios jame klaidos turi būti ieškomos dialoginiu būdu, dèl to didèja darbo sąnaudos. Todèl tikslinga būtų sukurti priemones, laidžiančias operatyviai automatizuotu būdu identifikuoti problematiškus modelio elementus.

Projektiniu variantu vertinimui ir sprendimu priemimams palengvinti turètụ būti praplèstas pagrindinių ir pagalbinių rodiklių sąrašas.

\section{Išvados}

Pastaty automatizuotos modeliavimo ir energetinès analizès sistemos programinèmis priemonèmis suformuo- 
ti realiu pastatu geometriniai modeliai, varijuojant jų detalumo laipsni. Suformavus pastaty modeliu projektu sprendimu alternatyvas, buvo atlikta energetinè ir ekonominè objektų ir jų dalių analizè. Atlikus variantini automatizuotą projektavimą ir analizę padarytos šios išvados:

1. Kompiuterinis pastato modelis gali būti parengtas tiek straipsnyje aptariamos sistemos priemonemis, tiek ir kitomis pramoninio kompiuterinio projektavimo sistemomis. Tačiau šis modelis turi būti sudarytas iš konkrečių tipų (3Dface, Region) geometriniu atžvilgiu korektišku grafinių objektų.

2. Architektūrinius objektų sprendimus (pagrindinių tūrių formas, matmenis, aukšto aukštị, aukštingumą ir pan.) patogiausia yra keisti pradinèje objektu detalizavimo stadijoje. Objektu atitvarų konstrukcinius sprendimus nesunkiai galima varijuoti bet kurioje objekto kūrimo stadijoje, nes ši procedūra nèra susijusi su pastato modelio geometrijos pakeitimu.

3. Priimti konstrukcinius sprendimus vartotojui palengvina iš anksto paruošta grafinè skaitmeninè duomenu bazè, kuri gali būti operatyviai papildoma darbo procese.

4. Naujai projektuojamo objekto varianty parinkimo pagrindinis vertinimo kriterijus šiuo metu specializuotoje sistemoje yra savitieji šilumos energijos nuostoliai $H_{T}$, nes šis rodiklis patogus vertinti projektu variantus, t. y. ivertina objekto geometriją ir konstrukciją, tačiau neatsižvelgia $i$ konkrečią statybos vietą. Renovuojamo objekto variantų analizei naudojama paprasta, bet pakankamai tiksli šiuo metu šalyje taikoma metodika, pagal kurią skaičiuojamas metinis šilumos suvartojimas $Q_{m e r}$ pastatui šildyti.

5. Projekto variantu parinkimas ekonominiu aspektu atliekamas tuomet, kai yra apšiltinamos atitvaros. Ekonominiai projektų variantu vertinimo kriterijai yra sutaupytos léšos $\Delta S$ ir atsipirkimo laikas $P B$ (paprastas) arba $P O$ (tikrasis).

6. Formuojant projektu variantus, vienu metu gali būti keičiami skirtingi dydžiai: geometriniai parametrai ir šiluminiai rodikliai. Taip galima išbandyti keletą alternatyvu ir parinkti energetiniu ir ekonominiu atžvilgiu racionaliausią erdvini ir konstrukcini sprendimus.

7. Eksperimentas, atliktas realių objektų pavyzdžiu, leido numatyti specializuotos sistemos tobulinimo kryptis:

- daugelis procedūru yra paprastos ir todèl lengvai valdomos, tačiau pasinaudoti visomis sistemos tei- kiamomis galimybèmis gali tik patyręs $C A D$ vartotojas;

- tikslinga sukurti parametrizuotu objektu formavimo ir redagavimo priemones;

- tikslinga parengti alternatyvių duomenụ struktūrų (pvz., CAD blokų, acocijuotu su atributiniais duomenimis) programines apdorojimo priemones;

- tikslinga sukurti priemones, padedančias automatizuotai lokalizuoti modeliavimo klaidas.

\section{Literatūra}

1. STR 2.05.01:1999. Pastatų atitvarų Šiluminè technika / Aplinkos ministerija. Vilnius, 1999. $132 \mathrm{p}$.

2. STR 2.01.03:1999. Statybinių medžiagụ ir gaminių šiluminių techninių dydžių deklaruojamosios ir projektinès vertès / Aplinkos ministerija. Vilnius. 1999. $25 \mathrm{p}$.

3. RSN 159 - 95. Šildymas, védinimas ir oro kondicionavimas. Vilnius, $1995.78 \mathrm{p}$.

4. RSN 156 - 94. Statybinè klimatologija / Statybos ir urbanistikos ministerija. Vilnius, 1995. $134 \mathrm{p}$.

5. Statau šiltą namą 97 . Pagalbinè priemonè projektuotojams ir statybininkams. Vilnius, 1995. $81 \mathrm{p}$.

6. NORGIPS gipso kartono plokščių statybos sistema. Pagalbiné priemone projektuotojams. statybininkams ir individualiems statytojams. Vilnius: Statybos literatūra. $1999.68 \mathrm{p}$.

7. Energịjos taupymas būste // Statyba ir architektūra. 1999 , Nr. 5.76 p.

8. V. Barkauskas. V. Stankevičius. Pastatụ atitvaru šiluminé technika. Kaunas: Technologija, 1997. $298 \mathrm{p}$.

9. Reference Manual. Energy. Softdesk, 1995. 56 p.

10. Рабоотаем с программным обеспечением фирмы Nemetschek (Allklima 2000. Решения Nemetschek по проектированию инженерных сетей // САПР и графика. 1999. ноябрь. Москва. с. 17-19.

11. Design and Renovation of Buildings to promote energy saving: Report on the training course for Baltic architects / Environmental Centre for Administration and Technology. Riga, 1994. 5 p.

12. AutoCAD Architectural Desktop R2. User's Guide. Autodesk. $1999.802 \mathrm{p}$.

13. Г. Елин. А. Конюхов. Выход версии ArchiCAD 6.0: событие месяца. а возможно. и года // САПР и графика. Москва: Из-во «Открытые системы». 1998. август. c. 83-87.

14. M. Gedgaudas. S. Paulauskaitė. M. Tamoševičius. Šilumos suvartojimas gyvenamųių namų šildymui norminiais (pagal klimatą) metais: Mokslinio darbo ataskaita. Vilnius. 1998. $17 \mathrm{p}$.

15. Energetikų auditorių mokỵmo kursai (moky̆mo medžiaga). Vilnius: Efektyvios energetikos mokymo centras, 1999 $267 \mathrm{p}$.

16. V. Stankevičius. G. Dapkus. A. Burlingis. Pastatų atitvaru apšiltinimo atsiperkamumas. Kaunas, 1997. 19 p.

Iteikta 20000404 


\section{FORMING AND AUTOMATED ENERGY ANALYSIS OF INTEGRATED MODELS OF THE PUBLIC BUIL- DINGS AND THEIR ENCLOSING STRUCTURES}

\section{G. Kazakevičiūtè, G. Cinelis, Z. Kamaitis}

\section{Summary}

The problem of energy saving and managing in buildings has become recently more acute.

The article concerns the modelling and energy analysis problem of the spatial and structural solutions in newly designed buildings or those under renovation. The results of that task serve as a base for defining thermal indices of the project at different design stages.

The core of the developed automated system is formed of integrated graphical digital spatial models of the parts of buildings. These models include different kind of structured geometric and non-geometric (physical, economical) information about the object. The method proposed is based on the open architecture CAD system and operates in the AutoCAD environment.

The automated building modelling and energy analysis system consists of such main parts: the subsystem of general geometric modelling of the building or building complex, the subsystem of the geometric modelling of the main building parts and structural components, the subsystem of analysis of models" geometry, the subsystem of analysis of models" energy, the subsystem of the project variants evaluation.

Modelling approaches for various design tasks, appropriate parts and the system possibilities are described in the article. According to definite design task intensions different methods were applied to the object.

During the approbation the principles put into the system. functional peculiarities, revealed the advantages and disadvantages of it were checked in practice. Two projects were chosen for the experiment (a shop and a school). These objects were different in architectural form, size, number of levels and other parameters. The buildings were modelled by various software tools but, in general, the approbation consisted of two stages:

1. The construction of geometric models and varying of geometric and structural parameters.

2. The energy analysis of integrated geometric models and comparison of the project variants or renovation measures.
Specific heat losses and annual consumption of heat energy are used as the main energy-related evaluation indices of the project.

An expert (an architect and/or an engineer) has a simple and intuitive tool as a set of operations for geometric transformations and calculation of project indices because the system is provided with modern user interface. It allows the user to work with the building projects operating in one graphical environment.

The proposed method could be used by interested experts as a tool for controlling thermal and energy indices at various design stages, searching for rational architectural forms and structural solutions. It takes into account the latest requirement of Lithuanian building regulations concerning heat energy saving.

Gerūta KAZAKEVIČIŪTÉ. PhD student (1994). Department of Engineering Graphics. Vilnius Gediminas Technical University (VGTU). Sauletekio al. 11, LT-2040 Vilnius, Lithuania. Email: k.geruta@is.lt

Research interests: computer graphics, CAD technologies and software, computer aided architectural design.

Gintaris CINELIS. Doctor. Department of Building Structures. Vilnius Gediminas Technical University (VGTU). Sauletekio al. 11. LT-2040 Vilnius, Lithuania. E-mail: g.cinelis@saf.ktu.lt

Doctor (CAAD), Moscow Civil Engineering Institute (1989). Research interests: methods of quantitative analysis in CAAD (mathematical models, computer graphics, CAD technologies and software).

Zenonas KAMAITIS. Doctor Habil, Professor. Director of International Studies Centre. Vilnius Gediminas Technical University (VGTU). Sauletekio al. 11. LT-2040 Vilnius, Lithuania. E-mail: tsc@ts.vtu.lt

Doctor (1968). Expert member of Lithuanian Academy of Sciences. Author and co-author of more than 150 publications, including 6 books. Research interests: concrete structures and bridges, materials, durability, monitoring. and refurbishment. 